\title{
Political Action Committees in State Elections
}

\author{
James D. King, University of Wyoming \\ Helenan S. Robin, Western Michigan University
}

\begin{abstract}
While the number of state PACs and their campaign contributions have increased substantially over the past decade, much remains unknown regarding their organization and activities. From a survey of PACs in three states we develop a portrait of political action committees which extends beyond contributions. State PACs form around both economic and ideological issues; have very modest organizational structures; solicit funds primarily by direct mail and personal contacts; typically delegate responsibility for making campaign contributions to committees which adopt accommodationist strategies; and have extended their activities to include voter education and mobilization. A number of differences among the various types of PACs are also evident.
\end{abstract}

Political action committees (PACs) are a relatively new and popular resource for campaign financing. The number of PACs at the federal, state, and local levels has increased sharply since the Federal Election Campaign Act of 1971 and subsequent rulings by the Federal Election Commission expanded the kinds of organizations that could form PACs and make campaign contributions. The ability of PACs to aggregate money from individual sources makes them appealing to individual candidates who spend large parts of their time trying to raise money for their campaigns. It is easier and more profitable to raise aggregated money from one source than from many individual contributions.

The rise of political action committees has not been without controversy. The low regard in which Americans generally hold interest groups and lobbyists has spilled over into public opinion of PACs. In the public's mind, PACs are seen as well-heeled "special interests" operating contrary to the public good (Rosenthal 1993, 5-8; Sabato 1985, 160-165). ${ }^{1}$ The large sums of money which PACs provide to individual candidates' electoral efforts have fueled the debate concerning interest groups "buying" legislative votes with their campaign contributions (Sabato 1985, 128-140; Sorauf 1988, 307-317). The relationship between political parties and PACs has also been disputed. Some analysts cite the rise of PACs as a major factor in the decline of parties (Crotty 1984, 133-134) while others perceive the

JAmes D. KING is Assistant Professor of Political Science at the University of Wyoming.

Helenan S. ROBIN is Professor of Political Science at Western Michigan University.

The American Review of Politics, Vol. 16, Spring, 1995: 61-77

${ }^{\circ} 1995$ The American Review of Politics 
campaign activities of parties and PACs as complementary (Adamany 1984; Herrnson 1988).

Because of the general interest in national-level politics and the availability of data filed with the Federal Election Commission, an abundance of research has been conducted on political action committees at the federal level. Much less attention has been directed toward state PACs despite the fact that there are far more public officials elected at the state level than at the national level. Analyses of campaign finance data from particular states have enhanced our understanding of the importance of PACs in state politics but have left many questions unanswered. Little is known, for example, of the structure and operation of state political action committees. The objective of this paper is to add to our knowledge of state political action committees by examining their organization and electoral activities with an eye toward distinctions among the varieties of state PACs.

\section{PACs in State Politics}

As Jones $(1984,172)$ noted, the study of campaign finance in state elections has been hindered by the vast number of elections contested at the state level and the absence of comparable data due to the states' varying campaign finance disclosure laws. Nonetheless, the findings from a number of studies of PACs and campaign funding in individual states enable us to develop a general profile of the PAC world below the national level.

The decade from the mid-1970s to the mid-1980s saw phenomenal increases in the cost of campaigns for Congress, the number of political action committees active in national politics, and the sums they contributed to candidates (Sorauf 1988, 53-54, 77-80). Although attracting much less attention from the media and public, these same patterns of increase are evident at the state level as well. Sorauf $(1988,262)$ noted that "[s]ince the middle 1970 s, the curve of state electoral spending matched the growth of spending in congressional campaigns." Spending in state campaigns jumped from an estimated \$95 million in 1972 to an estimated \$540 million in 1988, an increase of $468 \%$ (Alexander 1976, 78; Alexander and Bauer 1991, 3). In 1978 , candidates for governor in 36 states spent slightly less that $\$ 100$ million; eight years later, candidates in those same states spent nearly $\$ 256$ million (Beyle 1990, 53). While aggregated data are unavailable, the evidence from several states suggests a similar rise in the price of state legislative seats. For example, the cost of legislative campaigns tripled in Florida from 1972 to 1980 and in Colorado from 1974 to 1982 (Giles and Pritchard 1985, 75-76; Brace and Straayer 1987, 51). Similar changes in the cost of running for the state legislature occurred in Alaska, California, 
Missouri, New Jersey, Oregon, and Wisconsin as well (Jones 1984, 175; Sorauf 1988, 262-264; Syer 1987, 37-38). Perhaps Minnesota's experience between 1976 and 1980 best exemplifies the change in state campaign costs in this era, when a decrease in the number of candidates challenging for the state legislature coincided with an increase in overall campaign expenditures (Jones and Borris 1985, 92).

The number of political action committees in state politics has also been on the rise. Some states have experienced phenomenal increases in the number of PACs. In North Carolina from 1974 to 1989 the number of nonparty committees grew from 29 to 270 , a rate of increase of over $800 \%$ (Fleer 1992, 110). Over a period of just three years (1980-1983), Louisiana saw its number of PACs rise nearly $400 \%$, from 70 to 344 (Hadley and Nick 1987, 66). Perhaps more typical but still notable were a doubling of the number of PACs in both Wisconsin and New York from the late-1970s to the mid-1980s (Sorauf 1988, 269). In Missouri, the number of PACs increased only $34 \%$ from 1978 to 1986 but PAC expenditures jumped $407 \%$ during those same years (Casey and King 1993, 182). Oregon experienced substantial growth in both the number of PACS and PAC spending from 1974 to 1982, with the number of groups tripling and campaign contributions quadrupling (Hedrick and Zeigler 1987, 110). In 1974, PACs in Florida contributed $\$ 1.1$ million to state legislative campaigns; by 1989 , that figure had skyrocketed to $\$ 10$ million (Kelley and Taylor 1992, 135). Thomas and Hrebenar (1991) estimated that by 1990 there were more than 12,000 PACs active in state politics.

The importance of political action committee money in state elections extends beyond the number of PACs providing contributions and the number of dollars contributed. The proportion of candidates' total campaign funds that are obtained through PAC contributions has also increased. By the mid1980 s, roughly one-third of the funds for state legislative candidates in Kentucky, Missouri, and Pennsylvania came from PACs (Jewell and Miller 1992, 42; Casey and King 1993, 183; Eisenstein and Werner 1987). In California, North Carolina, and Washington, PACs have become the greatest source of campaign contributions (Sorauf 1988, 267; Fleer 1992, 111; Peterson 1987,129$)$. One study of the 1986 elections in Texas found that $61 \%$ of the campaign money raised by the speaker of the house, lieutenant governor, state representatives and state senators came from political action committees (Hamm and Wiggins 1992, 165-168).

National PACs have shown a clear preference for congressional candidates over presidential candidates and are noted for adopting rather conservative strategies in contributing to legislative campaigns, generally supporting incumbents rather than challengers and candidates in safe rather 
than marginal districts (Sabato 1985, 73-84; Sorauf 1988, 98-110). The evidence available from state campaign finance data suggests that state political action committees act similarly. Jones $(1984,189)$ noted that during the 1980 election PACs in Missouri and California gave little attention to statewide races, either for elected office or on ballot proposals. PACs in Colorado, Louisiana, Minnesota, North Carolina, and Pennsylvania have shown clear preferences for legislative incumbents over challengers (Brace and Straayer 1987, 53-54; Hadley and Nick 1987, 66-70; Jones and Borris 1985, 93-97; Fleer 1992, 111; Eisenstein and Werner 1987; see also, Jones 1984, 186-193).

In summary, political action committees have demonstrated a growing presence in state politics since the mid-1970s-there are more of them, they spend more, and they contribute a greater share of candidates' total campaign war chests. Like their brethren at the national level, state PACs prefer to support almost certain winners in legislative races rather than gamble by supporting marginal candidates or becoming involved in contests for executive office. National PACs are known to have modest organizations, solicit funds through a variety of techniques, and engage in limited voter education and mobilization programs (Eismeier and Pollock 1984; Sabato 1985). To what extent state PACs possess these characteristics is unknown, but it is the intent of this research to shed light on this matter.

\section{Methodology}

A mail survey of political action committees registered with election officials in Colorado, Michigan, and Tennessee during the 1990 campaign was conducted in an effort to learn about state PAC structure and operations. These states were selected to reflect geographic and political diversity. Michigan's electoral system is known for strong inter-party competition while Colorado's and Tennessee's tend to be dominated by the Republican and Democratic parties, respectively (Bibby et al. 1990, 92; Jewell and Olson 1988, 26-27). Interest groups in Tennessee are noted for wielding substantial influence, whereas those in Colorado and Michigan are considered important but less influential actors in the political process (Morehouse 1981, 108-112; Thomas and Hrebenar 1990, 147). Despite these differences, the 1990 election cycle saw the governor, at least one-half of the upper chamber of the legislature, and the entire lower chamber of the legislature elected in each state.

The four-page survey instrument (pre-tested in a 1986 pilot study) contained questions regarding office facilities, staff, fundraising, contributions, and other campaign-related activities. No effort was made to target 
groups by type or state; all organizations received the same questionnaire. Political action committees in Michigan and Tennessee were surveyed immediately after the 1990 election. Due to a delay in receiving the list of registered groups, the Colorado survey was conducted five months later. The survey involved two mailings, the second coming four weeks after the first. Each mailing included a questionnaire, business-reply envelope, and cover letter identifying the study's objectives and guaranteeing respondents' anonymity. In all instances, the questionnaire was addressed to the individual registered as treasurer of the organization. This procedure yielded 327 usable questionnaires, a $29 \%$ response rate. ${ }^{2}$ Following the common typology, PACs associated with corporations, labor unions, and trade associations are classified as such. All other political action committees are typed as nonconnected PACs (Sorauf 1988, 80-81). Multi-candidate committees affiliated with political parties have been excluded from the analysis.

\section{State PAC Structure and Operations}

The distribution of responding PACs by type demonstrates certain differences in the types of committees active at the state and national levels. Corporate PACS ( $25 \%$ of our state-level sample) and nonconnected PACs $(17 \%)$ are found in proportions smaller than at the national level while trade association PACs (47\%) and labor PACs (17\%) are more prevalent (Sabato 1985, 12-13; Sorauf 1988, 78). ${ }^{3}$ The national-state differences in the types of active PACs may reflect the political environments of the three states surveyed. But they also suggest a broader distinction between national and state politics. The stakes are extremely high in Washington, particularly regarding taxation, and it is in the interest of a large corporation to maintain a presence in national affairs. While not suggesting that the decisions of state governments are unimportant, the stakes are nevertheless likely to be lower in state capitals; a single corporation may not feel the need for individual action and may be more willing to be represented by an association. Furthermore, most professionals are regulated by state-not federalagencies. Thus, dental hygienists, optometrists, nurses, et cetera organize at the state level rather than the national level.

American federalism provides political groups with many avenues for participation and at least a portion of state PACs find each appealing. Political action committees registered with election officials in Colorado, Michigan, and Tennessee are almost universally active at the state level of government but are much less active at the national level. Ninety-three percent reported involvement in state politics while only $33 \%$ participated in national politics. 
Significant differences exist among the various types of PACs with respect to national-level involvement but not state-level campaign involvement. ${ }^{4}$ Corporate PACs were the most likely to be active at the national level $(67 \%)$, followed by nonconnected PACs $(28 \%)$, labor PACs $(27 \%)$, and trade association PACs $(15 \%) .{ }^{5}$ Not coincidentally, one-third of corporate PACs were also based outside the state in which they were registered. Although our data provide no direct evidence to the fact, it is nonetheless reasonable to assume that these PACs are the political arms of nationallyoriented corporations which delve into state politics as the need arises but have their attention directed primarily at Washington. On the other hand, trade association PACs appear to direct their attentions to the state level. These state PACs were least likely to be headquartered out of state and most likely to shun involvement in local or national politics. Again, this may stem from the fact that state government, rather than the national government, is principally responsible for regulating the businesses and professional which form trade associations.

\section{PAC Organizational Structure}

PAC organizations can own or rent whole buildings, have huge staffs, and operate with large budgets, or they can operate out of small, borrowed offices with little or no staff and budgets only large enough to pay for fundraising mailings or dues collections. For the most part, the latter characterizes state PACs. Only three percent of state PACs have their own offices, only eight percent have paid staff members, and only one percent have office budgets above $\$ 50,000$ (Table 1). On the other hand, $75 \%$ have no office, $56 \%$ have no permanent staff (relying instead on volunteers), and $88 \%$ have no budget for office operations.

The least well-developed organizations tend to belong to nonconnected PACs, with $88 \%$ having no office and no permanent staff and $92 \%$ having no office budget. Corporate, labor, and trade association PACs are most likely to borrow staff and office space from another organization, probably their parent institutions. The data in Table 1 may well underestimate the extent to which staff and space are borrowed by these PACs as the duties of a director and supporting staff may be assigned to a corporation's public affairs officer, a labor union's treasurer, a trade association's treasurer, or an interest group's chief lobbyist. Combining responsibilities in this way would be logical and produce a more efficient operation.

In short, it appears that the typical state political action committee is essentially a "desk drawer" operation in which one or two people have responsibility for keeping the records and processing communications but 
Table 1. State PAC Structural Arrangements

Non-

All Corporate Labor Trade connected

\section{OFFICE SPaCe}

Separate office

Part of larger office

\begin{tabular}{cccccc}
$3 \%$ & $4 \%$ & $4 \%$ & $2 \%$ & $4 \%$ \\
$\mathrm{~N}=$ & 22 & 16 & 29 & 30 & 9 \\
\cline { 2 - 2 } & $\frac{75}{100} \%$ & $100 \%$ & $\frac{67}{100 \%}$ & $\frac{69}{101 \%}$ & $\frac{88}{101 \%}$ \\
326 & 82 & 55 & 132 & 57 \\
$\mathrm{X}^{2}=14.30$ & $(6 \mathrm{df})$ & $\mathrm{p}<.05$ & $\mathrm{~V}=.15$
\end{tabular}

\section{OFFICE STAFF}

Paid staff

Part of other staff

$\begin{array}{cccccc}8 \% & 9 \% & 5 \% & 8 \% & 7 \% \\ \mathrm{~N}= & 37 & 45 & 31 & 47 & 5 \\ & \frac{56}{101} \% & \frac{46}{100 \%} & \frac{64}{100 \%} & \frac{44}{99 \%} & \frac{88}{100 \%} \\ & 325 & 80 & 55 & 133 & 57 \\ \mathrm{X}^{2}=37.56 & (6 \mathrm{df}) & \mathrm{p}<.001 & \mathrm{~V}=.24\end{array}$

\section{OFFICE BUDGET}

$\$ 0$

$\$ 1-\$ 5,000$

$\$ 5,001-\$ 20,000$

$\$ 20,001-\$ 50,000$

$\$ 50,001$ or more

\begin{tabular}{|c|c|c|c|c|c|}
\hline \multirow{6}{*}{ 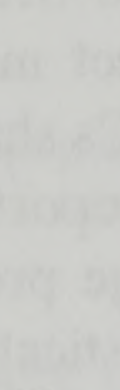 } & $88 \%$ & $84 \%$ & $90 \%$ & $88 \%$ & $92 \%$ \\
\hline & 7 & 7 & 6 & 7 & 8 \\
\hline & 2 & 4 & 2 & 2 & 0 \\
\hline & 2 & 1 & 2 & 3 & 0 \\
\hline & 1 & 3 & 0 & 0 & 0 \\
\hline & $100 \%$ & $99 \%$ & $100 \%$ & $\overline{100} \%$ & $\overline{100} \%$ \\
\hline \multirow[t]{2}{*}{$\mathrm{N}=$} & 292 & 69 & 49 & 122 & 52 \\
\hline & $X^{2}$ & & & & 11 \\
\hline
\end{tabular}

that no significant resources are devoted to PAC organization. Except for the obligation to register with the state election officials, they many not in fact be truly separate entities. This characterization may not square with the public's image of PACs and interest groups but it conforms to the realities of state government and politics. Discussions of the prominent role interest groups play in state politics often overlook the fact that many state-level interest groups are relatively modest operations as well. This is evidenced by the growing presence of professional lobbyists (also known as "contract lobbyists") who represent many clients simultaneously before the state legislature (Rosenthal 1993, 23-28; Thomas and Hrebenar 1990, 149). Various organizations affected by government activity typically find it more cost effective to contract for lobbyist services than to maintain an office in the 
state capital. Quite obviously, they also find it more cost effective to create very modest PAC organizations and operations.

\section{Campaign Finance}

Campaign finance is a double-edged sword. The expenditure side of campaign finance-contribution strategies and the impact of expendituresreceives the lion's share of attention from journalists and scholars, but expenditures must be preceded by revenues. As Sabato $(1985,52)$ noted: "Before PACs can contribute dollars, they must get them, and the solicitation of donors has very rapidly become both an art and a science." Thus, the importance of fundraising by political action committees cannot be overlooked.

There are many techniques by which organizations raise money, including direct mail solicitations, special fundraising events, organization newsletters, personal (face-to-face) appeals, telephone solicitations, and membership dues. State PACs utilize all of these methods plus others (Table 2). Direct mail, personal contact, and special events are the most popular methods for building campaign war chests with over two-fifths of responding PACs relying upon each technique. Reliance on direct mail and personal solicitations for fundraising is a characteristic state PACs share with national PACS, although each technique is used by larger proportions of national PACs (Sabato 1985, 54). It is also evident that a large proportion of state PACs have reached a certain level of political sophistication, as they are relying upon the solicitation techniques proven most effective in state election campaigns (Jones and Hopkins 1985). Other forms of solicitations are used less frequently but by substantial numbers of PACs. Approximately a quarter of state PACs use payroll deductions, telephone solicitations, and in-house communications to help fill their coffers.

The various types of political action committees are quite distinct in their approaches to fundraising. Corporate PACs tend to rely on payroll deductions and contributions solicited through internal communications but rarely use telephone solicitations. Labor PACs place the greatest emphasis on payroll deductions and use other solicitation techniques less frequently than do other types of groups. Trade association and nonconnected PACs appear to prefer direct mail, personal solicitations, and special fundraising events. As their reliance upon payroll deductions would suggest, corporate and labor PACs are most likely to request funds on a weekly or monthly basis (obviously tied to pay periods) while trade association PACs, nonconnected PACs, and party committees tend to conduct annual solicitations or to solicit funds when the staff deems it necessary. 
Table 2. State PAC Fundraising Techniques

Non-

All Corporate Labor Trade connected

Direct mail

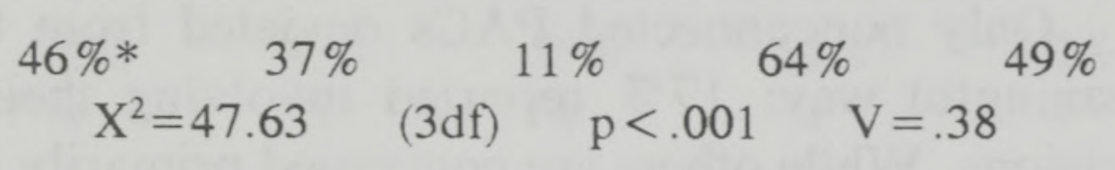

Personal contact

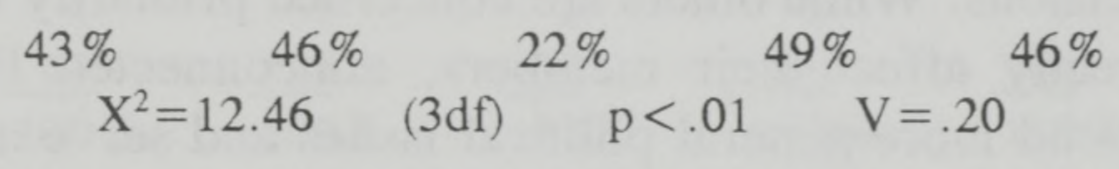

Special events

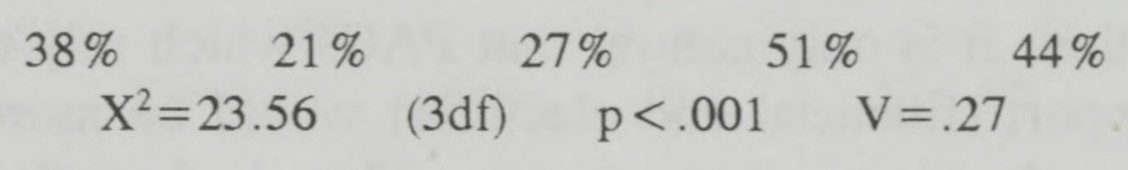

Payroll deduction

\begin{tabular}{|c|c|c|c|}
\hline $57 \%$ & 56 & $13 \%$ & $14 \%$ \\
\hline$X^{2}=70.74$ & $(3 \mathrm{df})$ & $\mathrm{p}<.001$ & $V=.47$ \\
\hline
\end{tabular}

Telephone

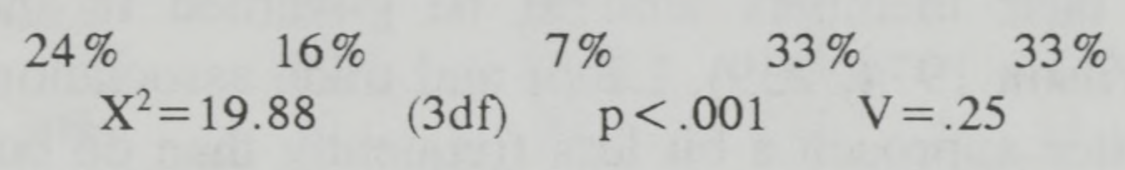

In-house memoranda
$25 \% \quad 50 \%$
$\mathrm{X}^{2}=38.73$

(3df) $\quad p<.001^{18 \%} \quad \mathrm{~V}=.34^{10 \%}$

Newsletter

$15 \% \quad 24 \%$
$\mathrm{X}^{2}=7.72$

$11 \% \quad 11 \%$

$16 \%$

(3df) $\quad p<.06 \quad V=.15$

*Percentage of responding PACs indicating that they solicited funds by each technique.

A key feature of state PAC fundraising is that a majority (61\%) use more than one technique. (This is a trait of national PACs as well; see Sabato 1985,53 .) While the mix of solicitation strategies varies from one group to another, it is clear that PACs have learned the advantages of adopting more than one tactic. Like an investment firm which relies upon a diverse portfolio to remain profitable, a typical political action committee does not gamble that one solicitation technique will provide all the funds needed to finance its activities. Corporate, trade association, and nonconnected PACs exhibit similar approaches to fundraising with roughly twofifths using three or more approaches. Labor PACs alone tend to limit their fundraising activities, as only $29 \%$ employed more than one method of solicitation.

The second side of political action committees' involvement in campaign finance concerns contributions to individual candidates. For the vast majority of state PACs, the principal responsibility for making these decisions falls to a committee. Nearly two-thirds $(65 \%)$ of the responding PACs reported that contribution decisions were commonly made by a committee or board of the PAC or the PAC's parent organization. Twenty-seven 
percent permitted one person-typically the PAC's executive director or the parent organization's chief lobbyist-to distribute campaign funds. Only eight percent of the PACs practiced pure democracy by allowing the organization's membership to vote on contribution decisions.

Only nonconnected PACs deviated from this general pattern in any meaningful way; $17 \%$ reported involving their members in contribution decisions. While others are concerned primarily with economic issues which directly affect their members, nonconnected PACs are typically formed around more general political issues and serve as vehicles for mass participation. It is only natural that PACs which rely upon individual citizens for support (financial and electoral) would be more willing to utilize a more open decision-making process. This, in fact, fits into the general pattern of political organizations as those organizations which provide material benefits to their members tend to be governed in the least-democratic fashion (Wilson 1974, 239). Labor and trade association PACs rely upon the committee approach a bit less frequently than do corporate PACs but the contrasts are not statistically significant and are reflective of differences among these types of PACs at the national level (Sabato 1985, 38-39).

Political action committees are faced with a series of choices in making contribution decisions, choosing between Republicans and Democrats, liberals and conservatives, incumbents and challengers. A PAC may adopt an "accommodationist" strategy, aiding incumbents and likely winners (often one and the same) in order to remain friendly with the in-coming government, or it may take an "adversarial" approach, supporting challengers and candidates who share policy perspectives with the group (Eismeier and Pollock 1984, 128). For the most part, state PACs are more likely to favor incumbents and candidates in safe districts and are less partisan and less ideological than are national PACs (Table 3; see also, Sabato 1985, 73-77). Nearly one half $(49 \%)$ of the state PACs reported favoring incumbents but almost as many $(43 \%)$ indicated no preference among candidates on this criterion. Only one PAC in five had a preference between candidates for the state house and state senate. Few differences among the various types of PACs are evident on either set of alternatives.

State PACs exhibit fairly sharp differences on partisan preferences. The most partisan state PACs are those affiliated with labor unions. Given organized labor's historical ties to that party, it is no surprise that $61 \%$ of labor PACs prefer Democrats; the remaining labor PACs express no partisan preference. Not a single labor PAC favored Republicans. Nearly one half of nonconnected PACs also have a partisan preference, with Republicans holding an edge over Democrats. Where partisan predilections exist, corporate and trade association PACs tend to favor Republicans but their 
Table 3. State PAC Preference Among Candidates

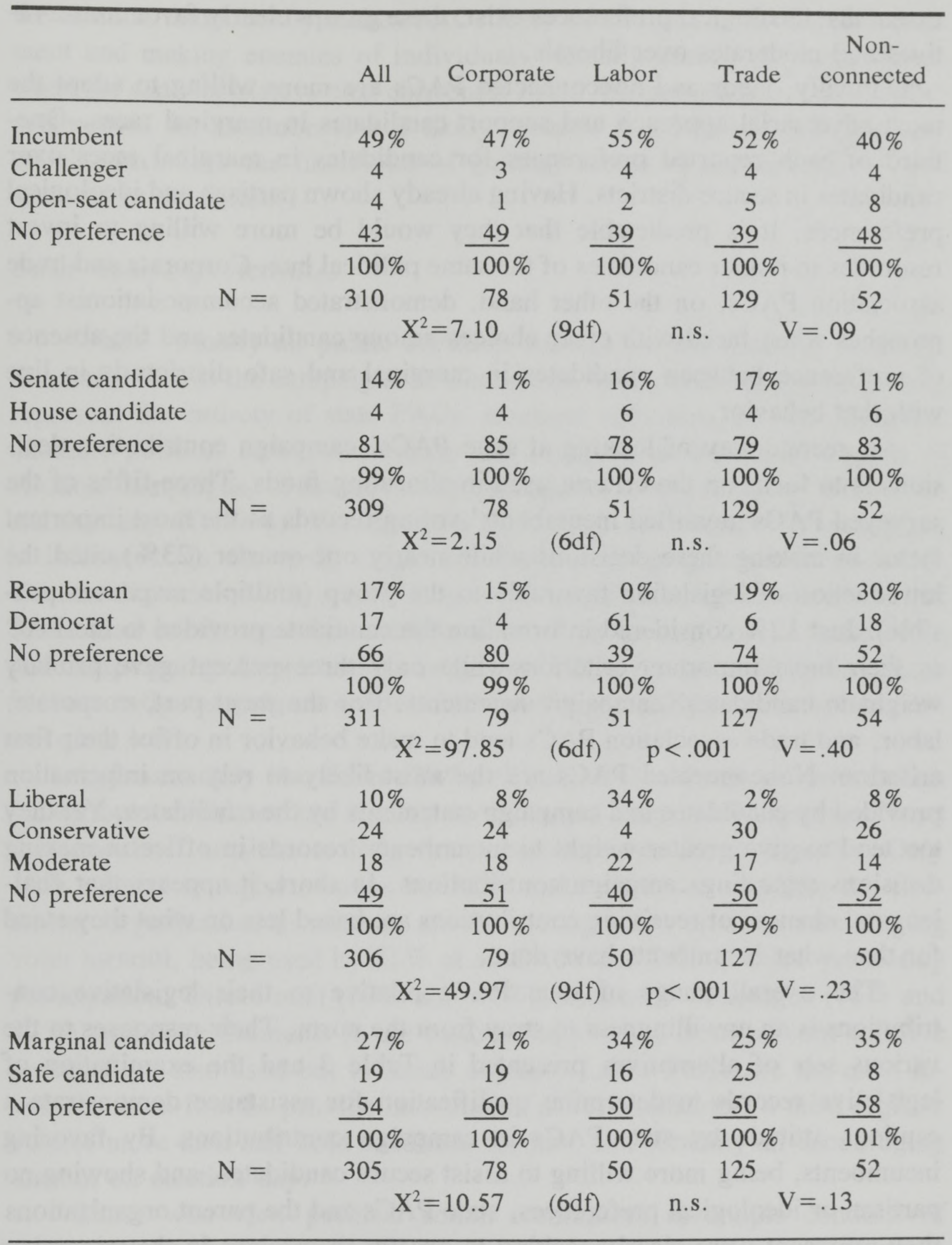

commitments to "no preference" are so overwhelming that partisanship is of little consequence. The strongest commitment to one ideological perspective is found among labor PACs, where more than one half of those with a preference side with liberals. Fifty percent of corporate, trade association, 
and nonconnected PACs acknowledge no ideological preferences but, to the extent that ideological preferences exist, these groups clearly favor conservatives and moderates over liberals.

Finally, labor and nonconnected PACs are more willing to adopt the most adversarial approach and support candidates in marginal races. Onethird of each reported preferences for candidates in marginal races over candidates in secure districts. Having already shown partisan and ideological preferences, it is predictable that they would be more willing to invest resources in riskier candidates of the same political hue. Corporate and trade association PACs, on the other hand, demonstrated accommodationist approaches when faced with other choices among candidates and the absence of preference between candidates in marginal and safe districts is in line with that behavior.

A second way of looking at state PACs' campaign contribution decisions is to focus on the criteria used in allocating funds. Three-fifths of the surveyed PACs identified incumbents' voting records as the most important factor in making these decisions while nearly one-quarter $(23 \%)$ cited the introduction of legislation favorable to the group (multiple responses possible). Just $12 \%$ considered information the candidate provided to the PAC as their most important criterion while only three percent gave primary weight to candidates' campaign statements. For the most part, corporate, labor, and trade association PACs tend to make behavior in office their first criterion. Nonconnected PACs are the most likely to rely on information provided by candidates and campaign statements by the candidates. Yet they too tend to give greater weight to incumbents' records in office in making decisions regarding campaign contributions. In short, it appears that challengers' chances of receiving contributions are based less on what they stand for than what incumbents have done.

The overall image of state PACs relative to their legislative contributions is an unwillingness to stray from the norm. Their responses to the various sets of alternatives presented in Table 3 and the examination of legislative records to determine qualification for assistance demonstrate a cautious attitude by state PACs in campaign contributions. By favoring incumbents, being more willing to assist secure candidates, and showing no partisan or ideological preferences, state PACs and the parent organizations they represent were clearly seeking to protect themselves in the upcoming legislative sessions. This strategy may be "primitive" and prevent a maximum return for the PAC's investment, as Jones and Borris $(1985,97)$ suggest, but it also gives due recognition to the absence of competition for state legislative seats, as trends point to increased incumbency advantage and the disappearance of marginal districts (Garand 1991; Weber et al. 1991). 
Knowing it is unlikely that their contributions will influence the outcome of the election undoubtedly makes PACs leery of straying from the establishment and making enemies of individuals virtually certain of being seated when the state legislature next convenes. From this perspective, state PACs' preferences for incumbents and likely winners is a rational strategy-one which maximizes the likelihood of gaining access to representatives and senators in the future.

\section{Other Campaign Activities}

While virtually all public attention focuses on the financial contributions of PACs to the campaigns of candidates, such contributions in no way represent the entirety of state PACs' electoral activities. To one degree or another, political action committees are involved in almost all aspects of election campaigns, from recruiting candidates to encouraging turnout on election day (Table 4). For the most part, PAC involvement in campaigns is infrequent in the early stages of election campaigns but increases as election day nears. Only one PAC in seven recruits candidates for office and fewer than one in ten helps candidates learn the ins and outs of fundraising and campaigning. Labor and nonconnected PACs are more likely to engage in these early-campaign activities although the percentages actively involved are quite low.

Approximately two-fifths (39\%) of state PACs distribute information on various candidates and slightly more than a third (36\%) sponsor "meet the candidate" sessions to help voters become more knowledgeable. Only $17 \%$ attempt to register voters but $68 \%$ make efforts to mobilize the electorate. Organization newsletters are the most popular mode of encouraging voter turnout, being used by $51 \%$ of all PACs and $74 \%$ of those promoting participation. Direct mail (30\% and $44 \%)$, telephone campaigns (15\% and $22 \%$ ), and advertisements in the various mass media (four percent and five percent) are also used but to lesser degrees. Labor PACs are the most involved; three-fourths provide information about candidates, a third register voters, more than half hold candidate forums, and virtually all encouraging turnout on election day.

Those who view political action committees as simple conduits of interest group funds to candidates overlook other important contributions that state PACs make to the electoral process. Seventy-six percent of the state PACs surveyed engage in at least one of the activities listed in Table 4; $50 \%$ undertake two or more. Early in the PAC era, Sorauf (1980, 453454) predicted that only nonconnected PACs were likely to develop and support the nonfinancial campaign activities that labor PACs had engaged 
Table 4. State PAC Campaign Activities

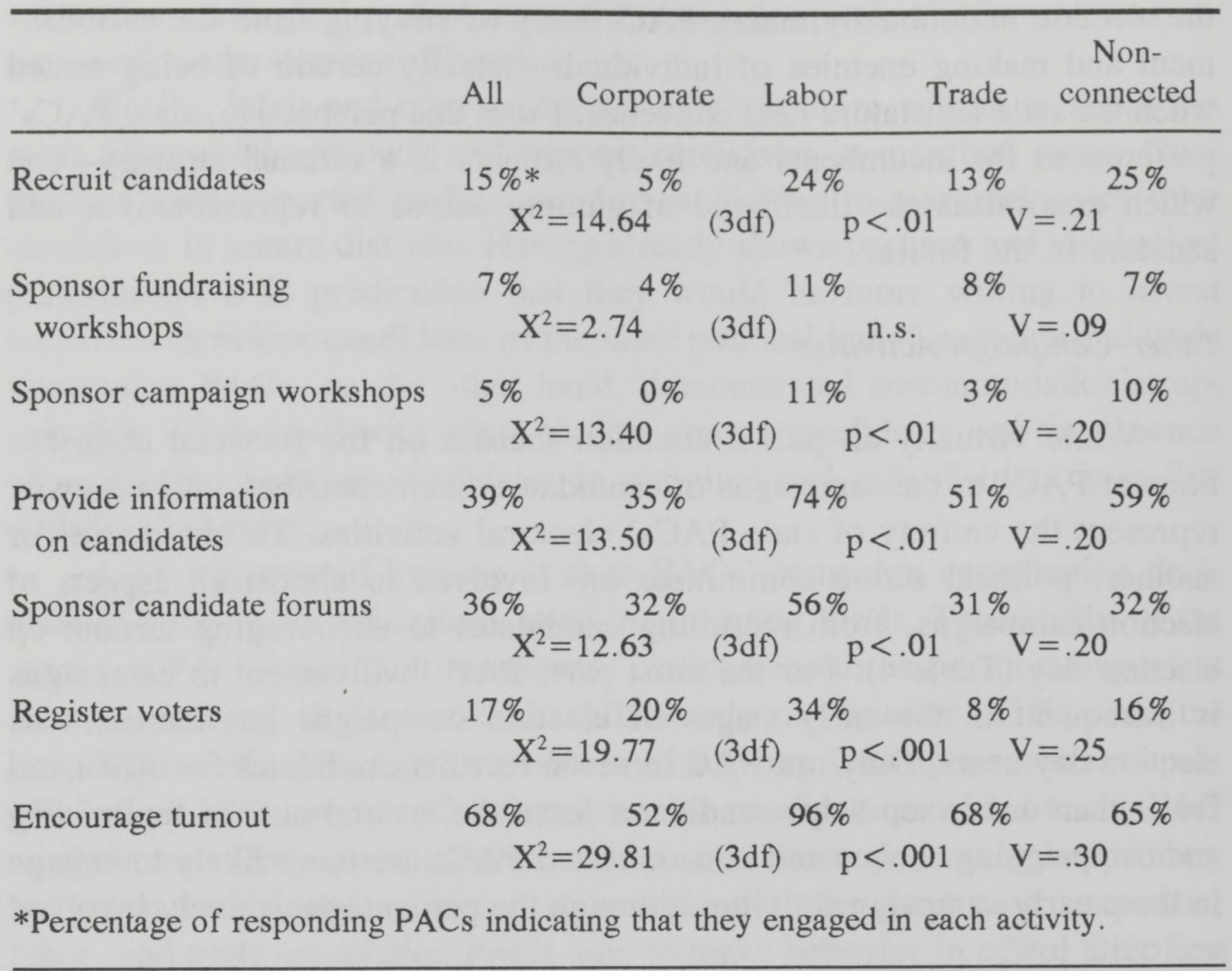

in for many years. Clearly, state-level nonconnected PACs have followed the labor PAC model of nonfinancial campaign involvement most closely. However, that PACs of all stripes have expanded their operations in these areas indicates that PAC directors have learned that providing candidates with campaign funds may not be sufficient to achieve the group's objectives and that there are benefits to be gained by recruiting candidates, making their contributors aware of candidates' positions on issues of concern, and getting them to the polls on election day.

\section{Summary}

Two aspects of state political action committee organization and activities warrant particular attention. First, despite popular images of PACs as highly developed organizations capable of dictating their will to public officials, state PACs tend to be rather modest operations. Extraordinary majorities have no distinct offices, no permanent staff, and no office budget. Instead, they borrow office space and staff from parent organizations or operate wherever they can with volunteer workers. Thus, PACs are 
comparable to other organized interests in state capitals, where groups hire professional lobbyists to do their bidding rather than establish their own offices.

Second, like their national counterparts, state PACs are not simply money machines, distributing their dollars among various candidates. The vast majority engage in other campaign-related activities, from recruiting candidates to providing members with information regarding candidates to mobilizing the electorate through voter registration and turnout efforts. In this way, state PACs have become more like political parties. Labor PACs have typically been viewed as the most "party-like" among political action committees (Sorauf 1992) and yet, to certain degrees, corporate, trade association, and nonconnected PACs also engage in what are traditionally party activities. This is not to suggest that political action committees are replacing political parties in the campaign process. The evidence on the vitality of state- and local-level party organizations is too strong to warrant such a conclusion. Rather, this characteristic of state PACs suggests that a supplementary or complementary relationship between PACs and parties is developing at the state level as well as the national level. Most clearly, political action committees have changed the landscape at all levels of the American political system.

\section{NOTES}

${ }^{1}$ Sabato $(1985,161-162)$ attributes PACs' low standing in public opinion polls to biased polling techniques and consistently negative reporting of PAC activity by the national news media.

${ }^{2}$ Our $29 \%$ response rate equals that achieved by Sabato $(1985,197-198)$ in his study of national PACs and is based on the full survey of multi-candidate committees, including both PACs and party committees. Only the data on PACs are incorporated into this article.

${ }^{3}$ In a comparison of PAC activity at the national level and in Louisiana, Hadley and Nick (1987, 66-67) observed substantially more nonconnected PACs and fewer corporate, trade association, and labor PACs at the state level. This may be somewhat deceptive, however, as they included political party committees among nonconnected PACs.

${ }^{4}$ The proportion of PACs active at the state level ranges from $87 \%$ of labor PACs to $96 \%$ of trade association PACs $\left(\mathrm{X}^{2}=6.06,3 \mathrm{df}\right.$, n.s., $\left.\mathrm{V}=.14\right)$.

${ }^{5}$ For the relationship between national-level involvement and PAC type: $\mathrm{X}^{2}=64.45$, $3 \mathrm{df}, \mathrm{p}<.001, \mathrm{~V}=.44$. 


\section{REFERENCES}

Adamany, David. 1984. Political Parties in the 1980s. In Money and Politics in the United States, ed. Michael J. Malbin. Washington, DC: American Enterprise Institute.

Alexander, Herbert E. 1976. Financing the 1972 Election. Lexington, MA: D.C. Heath. Alexander, Herbert E., and Monica Bauer. 1991. Financing the 1988 Election. Boulder, CO: Westview Press.

Beyle, Thad L. 1990. The Governors, 1988-89. In The Book of the States, 1990-1991 Edition. Lexington, KY: Council of State Governments.

Bibby, John F., Cornelius P. Cotter, James L. Gibson, and Robert J. Huckshorn. 1990.

Parties in State Politics. In Politics in the American States, ed. Virginia Gray, Herbert Jacob, and Robert B. Albritton. 5th ed.; Glenview, IL: Scott Foresman/ Little, Brown.

Brace, Paul, and John A. Straayer. 1987. Colorado: PACs, Political Candidates, and Conservatism. In Interest Group Politics in the American West, ed. Ronald J. Hrebenar and Clive S. Thomas. Salt Lake City: University of Utah Press.

Casey, Gregory, and James D. King. 1993. Missouri: From Establishment Elite to Classic Pluralism. In Interest Group Politics in the Midwestern States, ed. Ronald

J. Hrebenar and Clive S. Thomas. Ames: Iowa State University Press.

Crotty, William. 1984. American Parties in Decline. 2nd ed.; Boston: Little, Brown. Eisenstein, James, and Brian Werner. 1987. Party Committee and PAC Contributions to Legislative Candidates in Pennsylvania: 1976-1984. Paper presented at the annual meeting of the American Political Science Association, Chicago.

Eismeier, Theodore J., and Philip H. Pollock III. 1984. Political Action Committees: Varieties of Organization and Strategy. In Money and Politics in the United States, ed. Michael J. Malbin. Washington, DC: American Enterprise Institute.

Fleer, Jack D. 1992. North Carolina: Interest Groups in a State in Transition. In Interest Group Politics in the Southern States, ed. Ronald J. Hrebenar and Clive S. Thomas. Tuscaloosa: University of Alabama Press.

Garand, James C. 1991. Electoral Marginality in State Legislative Elections, 1968-1986. Legislative Studies Quarterly 16:7-28.

Giles, Michael W., and Anita Pritchard. 1985. Campaign Expenditures and Legislative Elections in Florida. Legislative Studies Quarterly 10:71-88.

Hadley, Charles D., and Rainer Nick. 1987. The Two Step Flow of State Campaign Funds: PACs As Donors and Receivers in Louisiana. Western Political Quarterly 40:65-77.

Hamm, Keith E., and Charles W. Wiggins. 1992. Texas: The Transformation from Personal to Informational Lobbying. In Interest Group Politics in the Southern States, ed. Ronald J. Hrebenar and Clive S. Thomas. Tuscaloosa: University of Alabama Press.

Hedrick, William H., and L. Harmon Zeigler. 1987. Oregon: The Politics of Power. In Interest Group Politics in the American West, ed. Ronald J. Hrebenar and Clive S. Thomas. Salt Lake City: University of Utah Press.

Herrnson, Paul S. 1988. Party Campaigning in the 1980s. Cambridge: Harvard University Press. 
Jewell, Malcolm E., and Penny M. Miller. 1992. Kentucky: Adapting to the Independent Legislature. In Interest Group Politics in the Southern States, ed. Ronald J. Hrebenar and Clive S. Thomas. Tuscaloosa: University of Alabama Press.

Jewell, Malcolm E., and David M. Olson. 1988. Political Parties and Elections in the American States. 3rd ed.; Chicago: Dorsey Press.

Jones, Ruth S. 1984. Financing State Elections. In Money and Politics in the United States, ed. Michael J. Malbin. Washington, DC: American Enterprise Institute.

Jones, Ruth S., and Thomas J. Borris. 1985. Strategic Contributing in Legislative Campaigns: The Case of Minnesota. Legislative Studies Quarterly 10:89-105.

Jones, Ruth S., and Anne H. Hopkins. 1985. State Campaign Fund Raising: Targets and Response. Journal of Politics 47:427-449.

Kelley, Anne E., and Ella L. Taylor. 1992. Florida: The Changing Patterns of Power. In Interest Group Politics in the Southern States, ed. Ronald J. Hrebenar and Clive S. Thomas. Tuscaloosa: University of Alabama Press.

Morehouse, Sarah McCally. 1981. State Politics, Parties, and Policy. New York: Holt, Rinehart, and Winston.

Peterson, Walfred H. 1987. Washington: The Impact of Public Disclosure Laws. In Interest Group Politics in the American West, ed. Ronald J. Hrebenar and Clive S. Thomas. Salt Lake City: University of Utah Press.

Rosenthal, Alan. 1993. The Third House: Lobbyists and Lobbying in the States. Washington, DC: CQ Press.

Sabato, Larry J. 1985. PAC Power: Inside the World of Political Action Committees. New York: W.W. Norton \& Company.

Sorauf, Frank J. 1980. Political Parties and Political Action Committees: Two Life Cycles. Arizona Law Review 22:444-463. Company.

. 1988. Money in American Elections. Glenview, IL: Scott, Foresman and

. 1992. Inside Campaign Finance: Myths and Realities. New Haven: Yale University Press.

Syer, John C. 1987. California: Political Giants in a Megastate. In Interest Group Politics in the American West, ed. Ronald J. Hrebenar and Clive S. Thomas. Salt Lake City: University of Utah Press.

Thomas, Clive S., and Ronald J. Hrebenar. 1990. Interest Groups in the States. In Politics in the American States, ed. Virginia Gray, Herbert Jacob, and Robert B. Albritton. 5th ed.; Glenview, IL: Scott Foresman/Little, Brown.

1991. Political Action Committees in the States: Some Preliminary Findings. Paper presented at the annual meeting of the American Political Science Association, Washington, DC.

Weber, Ronald E., Harvey J. Tucker, and Paul Brace. 1991. Vanishing Marginals in State Legislative Elections. Legislative Studies Quarterly 16:29-47.

Wilson, James Q. 1974. Political Organizations. New York: Basic Books. 